\title{
STEPINČEVI INTERVENTI KOD PAVELIĆA
}

\author{
Ratko PERIĆ, biskup \\ Nadbiskupa Cule b.b. \\ $\mathrm{BiH}$ - 88000 Mostar \\ E-pošta: cbismo@gmail.com
}

UDK: $94(497.5) " 1941 / 1945 "$
$272(497.5) " 1941 / 1945 "$
Pregledni rad
Primljeno: 11. lipnja 2017.
Prihvaćeno: 4. srpnja 2017.

\section{Sažetak}

Srpski patrijarh Irinej Gavrilović obratio se deveterostraničnim pismom papi Franji, 30. travnja 2014., moleći ga da s dnevnoga reda skine kanonizaciju mučenika blaženoga Alojzija Stepinca, zagrebačkoga nadbiskupa (od 1934. koadjutor, od 1937. do 1960. ordinarij, od 1946. sede impedita - u zatvoru do 1952. i u zatočeništvu do smrti). Razlog protiv kanonizacije: nadbiskup je Stepinac "uglavnom šutio" na sve ono što se događalo u Nezavisnoj Državi Hrvatskoj. A tko šuti, pristaje. Takav crkveni predstavnik ne može biti uzor kršćanskomu puku. Auktor na temelju gradiva objavljena prije Patrijarhova pisma prikazuje da je nadbiskup Stepinac u vrijeme četverogodišnjega trajanja $\mathrm{NDH}$ od 10. travnja 1941. do 8. svibnja 1945. ili točnije kroz 48 mjeseci intervenirao više od 360 puta bilo u osobnim susretima s nositeljima hrvatske vlasti u Zagrebu bilo dopisima pojedinim hrvatskim ministrima, bilo u javnim propovijedima, nagovorima, predavanjima. Napose se usredotočio na kontakte između nadbiskupa Stepinca i poglavnika Ante Pavelića. Sažeto je i kronološki prikazao 21 dopis Stepinca Paveliću i 11 susreta Stepinca i Pavelića s kratkim komentarima. Pavelić nije uzvratio ni na jedan posjet niti je osobno odgovorio i na jedan Stepinčev do- 
pis. Unatoč tomu, Nadbiskup je bio uporan i nepopustljiv i intervenirao je uvijek kada je smatrao potrebnim to učiniti, bez obzira koliko se političke vlasti osjećale neraspoloženima zbog njegovih dopisa, molbi i zahtjeva. Nije, dakle, nadbiskup Stepinac šutio, nego je govorio, pisao i posredovao koliko je više mogao, ne gledajući na rezultate svojih intervenata. Barem se ne može reći da je nadbiskup Stepinac "uglavnom šutio" na sve što se događalo za vrijeme NDH. Kada je Pavelić vidio da je sve propalo i da mora bježati iz Hrvatske, pozvao je nadbiskupa Stepinca i ponudio mu da preuzme vlast u Hrvatskoj. Stepinac je odbio političku vlast ostajući na svome nadbiskupskom mjestu.

Ključne riječi: papa Franjo; patrijarh Irinej; blaženi Alojzije Stepinac, nadbiskup; poglavnik Ante Pavelić; Nezavisna Država Hrvatska; Hrvatska biskupska konferencija.

Uvod. Patrijarh Irinej Gavrilović, potpisujući 9-stranično pismo, u ime Svetoga Sinoda Srpske Pravoslavne Crkve, upućeno papi Franji, 30. travnja 2014., na str. 6-7, govori o odlučnoj osudi nacizma u govoru pape emeritusa Benedikta XVI., te kaže: "kakav se samo strašan obrt [obrat?] desio u Hrvatskoj, gde se u ovo bogoubistvo uključio, u znatnom broju, i rimokatolički klir, ali ne u ime izmišljene neopaganske vere nego u ime Crkve, na čijem ste Vi danas čelu! I šta je sa takvim predstavnicima jerarhije i klira - biskupima, sveštenstvom, redovnicima - činio kardinal Stepinac? Moramo se suočiti sa činjenicom da je, nažalost, uglavnom ćutao".

Ovdje bismo željeli dokazati da nije istinita ta Patrijarhova optužba, jer zagrebački nadbiskup Alojzije Stepinac (kardinalom je postao tek 1953.!), nije uopće šutio, nego je iz tjedna u tjedan sustavno pisao ${ }^{2}$ - 211 pisanih svjedočanstava iz Nadbiskupove ruke ili ureda, i su-

1 https://www.srbijadanas.com/vesti/srbija/ekskluzivno-pismo-patrijarha-irineja-papi-stepinac-je-cutao-kada-su-ustase-ubijale-pravoslavne-2016-10-16 (4. 11. 2016.).

2 Stepinčeva korespondencija s državnim vlastima i raznim organizacijama od 10. travnja 1941. do 8. svibnja 1945. objavljena je u djelu: JuRAJ BATELJA (prir.), Blaženi Alojzije Stepinac - svjedok Evanđelja ljubavi (dalje: BAS), Postulatura blaženog Alojzija Stepinca, Zagreb, 2010., sv. II., str. 116-618; sv. III., str. 5-125. 
stavno propovijedao ${ }^{3}-111$ propovijedi i raznih nagovora i poruka, a izravno i u oči samomu poglavniku dr. Anti Paveliću barem 21 put napismeno i 11 puta osobno u susretu. Dakle u 48 mjeseci postojanja Nezavisne Države Hrvatske Nadbiskup nije "uglavnom ćutao", nego je 362 puta javno govorio i zauzimao se pismom i djelom, eto ne iz tjedna u tjedan, nego, u prosjeku, svaki četvrti dan. I to je bilo sve objavljeno prije negoli je patrijarh Irinej iznio svoju dezinformaciju i difamaciju pred papu Franju na račun nadbiskupa Stepinca.

Ovdje ćemo samo o izravnim odnosima, u susretima i korespondenciji, između zagrebačkoga nadbiskupa Alojzija Stepinca i poglavnika Nezavisne Države Hrvatske Ante Pavelića za vrijeme NDH.

Ante Pavelić, sin ličkih roditelja, rođen u Bradini župa Konjic, 14. srpnja 1889. Gimnaziju pohađa u Travničkoj gimnaziji, 1902.-1906. Doktorira pravo u Zagrebu 1915. Zastupnik na listi Hrvatskoga bloka 1927. Svjedok atentata na hrvatske zastupnike u beogradskoj skupštini 1928. Osnivač revolucionarno-ustaške organizacije u emigraciji od početka 1929. U odsutnosti u Beogradu osuđen na smrt. Poglavnik NDH 1941.-1945. Bježi iz zemlje u svibnju 1945. i preko Austrije i Italije dospijeva u Argentinu. Nakon preživjela atentata 1957., bježi iz Argentine u Španjolsku, gdje umire 28. prosinca 1959.

Alojzije Stepinac, rođen u Brezariću, župa Krašić, 8. svibnja 1898. Gimnaziju pohađa u Zagrebu. Dvije posljednje godine kao sjemeništarac. Nakon mature 1916. dignut u vojsku u Italiju. Na bojišnici ranjen i zarobljen. Solunsko bojište probijeno je 15. rujna 1918., a on se vraća u prosincu preko Soluna u Hrvatsku. Ne sudjeluje u borbama srpske vojske. Umjesto na bogosloviju upisuje se na agronomiju, 1919. Ipak odlazi u bogosloviju u Rim 1924. Doktorira filozofiju i teologiju na Gregorijani. Zaređen za svećenika 1930. Vraća se u Zagreb 1931. Imenovan zagrebačkim nadbiskupom koadjutorom 1934. Postaje rezidencijalnim 1937. Osuđen na 16 godina zatvora i daljnjih 5 godina lišen ljudskih prava 1946. Iz lepoglavskoga zatvora premješten u zatočeništvo u Krašić 1952., gdje umire 10. veljače 1960. Proglasio ga papa Ivan Pavao II. mučenikom i blaženikom na Mariji Bistrici, 3. listopada 1998.

3 Stepinčevi javni nastupi objavljeni su u djelu: Juraj BATELJA (prir.), BlažEni Alojzije Stepinac, Propovijedi, govori, poruke 1941.-1946., Postulatura blaženog Alojzija Stepinca, Zagreb, 2012. 
Providnost je Božja vodila Stepinca kroz trogodišnju vojsku, zarobljeništvo i ranjavanje u Prvom svjetskom ratu, kao da ga je spremala za Drugi svjetski i još teži rat. Treba odmah reći da je nadbiskup Stepinac, kao iskren rodoljub, poučen gorkim iskustvom dviju državnih tvorevina, Austro-Ugarske i Kraljevine Jugoslavije, u kojima se hrvatski narod osjećao zapostavljenim, izričito bio za samostalnu i neovisnu hrvatsku državu i 1941. i $1945 .{ }^{4}$ I da to nije smatrao nikakvim zločinom, nego izrazom duboke domoljubne svijesti. On je državu bitno razlikovao od konkretna režima, ${ }^{5}$ i ustaškoga 1941. i komunističkoga $1945 .{ }^{6}$ Stoga su njegovi pothvati išli za tim da se hrvatska država kao pravna institucija učvrsti i spasi, kao podloga za slobodu Crkve i naviještanja vjere, a da se režimske ljude popravlja i poziva na poštovanje Božjega zakona, koliko je moguće. A tu je upravo temeljni prigovor dobra dijela srpskoga vodstva, pogotovo velikosrpstva, pa i dijela Srpske Pravoslavne Crkve: Hrvati ne smiju imati nikakvu državnu tvorevinu:

ni Državu SHS [Slovenaca, Hrvata i Srba] koja je trajala od 29. listopada do 1. prosinca 1918.;

ni Banovinu Hrvatsku od 26. kolovoza 1939. do 27. ožujka 1941.;

ni Nezavisnu Državu Hrvatsku od 10. travnja 1941. do 8. svibnja 1945.;

ni opravdane zahtjeve za većom državnom autonomijom 1971., kada se čulo iz usta druga Maršala da će prije Sava poteći od Zagreba prema Ljubljani negoli Hrvati imati svoju državu;

4 Marina ŠTambuk-ŠKalić, "Dokumenti obrane u sudskom procesu protiv nadbiskupa Alojzija Stepinca", u: Fontes - Izvori za hrvatsku povijest, 2, Zagreb, 1996., str. 90-94. Navodimo sa str. 91: "Ako mislite, da je hrvatski narod zadovoljan s ovom sudbinom, ili da mu još eventualno pružite priliku, da se izjasni s moje strane nema poteškoća. Poštivao sam i poštivat ću volju svoga naroda."

5 Poznata je njegova rečenica: "Hrvatska država je politički cilj svih dobrih rodoljuba, ali režim nije država", L. BRAjnovich, "Un defensor de la fe" u: Stepinac (3), El Alcazar, od 21. veljače 1960., str. 2. Navedeno u: IvaN Mužıć, Pavelić i Stepinac, Logos, Split, 1990., str. 78, vidi bilj. 55.

6 "Nisam radio protiv prve Jugoslavije, nisam radio niti protiv ustaške vlade, niti sam radio protiv komunističke države. To su stvari političara. Ali ako je bilo štogod protiv moralnih i vjerskih načela, kao biskup nisam mogao šutjeti", Aleksa Benigar, Alojzije Stepinac, hrvatski kardinal, ZIRAL, Rim, 1974., str. 580 . 
ni 1991. godine kada je uspostavljena Republika Hrvatska! I upravo ti prigovaratelji poistovjećuju poglavnika Pavelića s NDH! Što je god učinio Pavelić, to je učinila NDH!

Ipak Stepinac nije bio toliko politički zanesen državom da bi je preferirao svojoj crkvenoj nadbiskupskoj službi i sam se stavio kao vođa na čelo države kao što mu je Pavelić sugerirao kada je vidio da je sve propalo! "Pavelić mi nudi, da preuzmem vlast. Ni čuti o tome. To je Vaša stvar, kome ćete predati vlast, rekao sam mu. U politiku se ne miješam, nego ostajem tu, pa što bilo, da bilo."7 Stepinac je ostao u Zagrebu na svome mjestu. Bio je na svome mjestu i u Lepoglavi, na svome mjestu i u Krašiću, kao što je i danas na svome mjestu u zagrebačkoj katedrali iza glavnoga oltara! Sada je na svome mjestu - na oltaru! Pavelić nije bio na svome mjestu ni 1941. ni 1945. godine!

\section{Predratno doba}

Stepinac veleposlaniku Mirošević-Sorgi, 17. listopada 1940. - Uoči Drugoga svjetskog rata, pod nadnevkom 17. listopada 1940. nadbiskup Stepinac piše: "Danas je bio kod mene naš poslanik kod Vatikana g. Mirošević-Sorgo. Došao je opet da tuži neke svećenike iz dalmatinske biskupije da pristaju i pomažu Pavelića. Ja sam ga upozorio da je Pavelića stvorio Beograd i ludi centralizam." ${ }^{\text {" }}$

- Niko Mirošević-Sorgo, ${ }^{9} \mathrm{u}$ ime jugoslavenske vlade, dolazi k Stepincu žaliti se na neke svećenike iz Dalmacije koji kontaktiraju s Pavelićem u Italiji, a Nadbiskup podsjeća veleposlanika na činjenicu da je nakon ubojstva četvorice hrvatskih zastupnika u lipnju 1928. u beogradskoj skupštini i smrti Stjepana Radića u kolovozu od posljedica toga atentata nastala u siječnju 1929. ustaška prevratnička organizacija u inozemstvu, a jugoslavenska vlada uvela protunarodnu diktaturu 1929. i Oktroirani ili nametnuti ustav 1931. proizvodeći "ludi centralizam".

7 Josip Vraneković, Dnevnik. Život u Krašiću zasužnjenog nadbiskupa i kardinala Alojzija Stepinca, Postulatura blaženog Alojzija Stepinca, Zagreb, 2011., pod nadnevkom: 29. IV. 1954., str. 297. Vidi i str. 463.

8 Alojzije Stepinac, Dnevnik, sv. IV. [neobjavljeno], pod datumom: 17. X. 1940. Dnevnik se nalazi u Postulaturi u Zagrebu.

9 Niko Mirošević-Sorgo (Dubrovnik, 1885. - London, 1966.), jugoslavenski veleposlanik pri Svetoj Stolici (1937.-1945.), zapravo samo do svršetka srpnja 1941., kada je prognan iz Italije. Njegova se dokumentacija nalazi u Arhivu Jugoslavije u Beogradu pod siglom: "Osobni arhiv Niko Mirošević-Sorgo", fasc. 21 , fond 372 . 
Stepinac ne brani Pavelića, niti ga uopće pozna, nego ističe načelo: Ukloni, veleposlaniče, uzroke, pa ne će biti ni posljedica!

Stepinac nunciju Feliciju, 16. studenoga 1940. - "Jučer je otputovao Nuncij u Beograd nakon boravka od 7 dana u Zagrebu. Došao je po želji Sv. Oca da se informira povodom tužbe sa strane Kr.[aljevske] vlade o političkoj akciji svećenstva na strani Pavelića. Vlada je ogorčena, a i Maček je u dvosatnom razgovoru s Nuncijem iznio svoje žaljenje. Međutim Pavelića nije stvorila katolička Crkva nego luda beogradska politika. Nakon što je Nuncij izložio tužbu ustao sam kao predsjednik Konferencije i u ime cijelog Episkopata iznio sva gravamina [pritužbe] Crkve katoličke u Jugoslaviji protiv beogradskih nepravda i nasilja. Rekao sam otvoreno ako se ne uvede pravda i ne zavlada poštenje, Jugoslavija će se sama raspasti. Crkva odnosno biskupi ne može zavezati jezika narodu koji trpi od nepravda svake ruke. Nuncij je vidio da ima toga vrlo mnogo zbog čega se mi moramo žaliti više nego vlada na nas." ${ }^{10}$

- Nadbiskupu ni ovdje nije bio cilj opravdavati svećeničke kontakte s Pavelićem u Italiji, nego podsjetiti na sve "beogradske nepravde i nasilja", koja potječu od države kao institucije, odakle bi se očekivala pravda! Ne mogu biskupi zavezivati usta hrvatskomu narodu koji trpi od svakovrsnih nepravdi! Jasno i odlučno!

\section{Ratno doba}

Proglašenje NDH. - Na Veliki četvrtak, 10. travnja 1941. umirovljeni pukovnik Slavko Kvaternik na zagrebačkom Radiju proglašava $\mathrm{NDH}$, koja traje pod pokroviteljstvom Mussolinijeve fašističke Italije do bezuvjetne kapitulacije 8. rujna 1943. i Hitlerove nacističke Njemačke do bezuvjetne kapitulacije 7. svibnja 1945.

"Na Veliku subotu [12. IV. 1941.] prije podne je preuzv. g. nadbiskup dr. A. Stepinac učinio službeni posjet Zamjeniku Poglavnika Države Hrvatske, generalu g. Slavku Kvaterniku. Tom je prigodom izrazio svoje čestitke prigodom obnove državne nezavisnosti."11

10 A. Stepinac, Dnevnik, sv. IV., pod nadnevkom 16. studenoga 1940.

11 Katolički list, Zagreb, 16/1941., 22. travnja, str. 195. 
- Nadbiskup se kao istinski domoljub raduje uspostavi hrvatske države. On je to jasno izrekao i te 1941. i na montiranom komunističkom sudu 1946.: "Hrvatski se Narod plebiscitarno izjasnio za Hrvatsku državu i ja bih bio ništarija, kad ne bih osjetio bilo Hrvatskog Naroda, koji je bio rob u bivšoj Jugoslaviji."12

Pavelićev dolazak u Zagreb. - Stepinčev životopisac fra Aleksa Benigar bilježi: "Pavelić stigne, 14. travnja [1941.], u Zagreb, kad se već spustio mrak. Zbog toga je izostao doček, koji mu se pripravljao. Sutradan, 15. travnja, dr. Pavelić dade preko radija obavijest, da je u svoje ruke preuzeo vlast u Nezavisnoj Državi Hrvatskoj u hrvatskom glavnom gradu Zagrebu."13

- Sada će čovjek, koji živi pod utegom smrtne kazne izrečene od beogradskih vlasti zbog "veleizdaje" (17. srpnja 1929.), kada preuzme vlast u svoje ruke pokazati koliko je moćan nadići strastvene osjećaje osvete i mržnje.

Stepinčev prvi susRet s Pavelićem, 16. travnja 1941. - "U srijedu 16. o. mj. [1941.] primio je Poglavnik Države Hrvatske dr A. Pavelić u posebnu audijenciju zagrebačkog nadbiskupa i metropolitu hrvatske crkvene pokrajine preuzv. g. dra Alojzija Stepinca."14

Sadržaj razgovora: "Prvih dana nakon povratka Poglavnika imao je Nadbiskup prvi sastanak s njime u nekadanjim Banskim Dvorima. Niti je prije Poglavnik poznavao Nadbiskupa niti Nadbiskup njega. Razgovor je trajao poprilici petnaest minuta. Nadbiskup mu je poželio Božji blagoslov u radu i naglasio da se Crkva ni do sada nije miješala niti se želi ubuduće miješati u aktivnu politiku. Nadbiskup samo jedno moli od Poglavnika i nove državne vlasti, naime da se poštivaju katoličke tradicije naroda i omogući Crkvi slobodno djelovanje.

Poglavnik je pozorno slušao, dok je Nadbiskup govorio. Možda i za to što je čuo po svoj prilici s raznih strana da je Nadbiskup bio tobo-

12 A. Benigar, nav. dj., str. 584. O povijesnom putu rečenice: "Hrvatski se narod plebiscitarno izjasnio za Hrvatsku državu" vidi osvrt: R. P., "Vrijednost i važnost Stepinčevih propovijedi", u: J. Batelja, (prir.), Blaženi Alojzije StePinac, Propovijedi, govori, poruke 1941.-1946., str. 10-14.

13 A. Benigar, nav. dj., str. 361.

14 Katolički list, Zagreb, 16/1941., 22. travnja, str. 195. 
že na solunskom frontu (kao Šubašić) i prema tome 'jugoslavenski' orijentiran što je dakako fabula, ako se to tvrdilo u smislu da želi centralističku Jugoslaviju sa dominacijom Srba. Poglavnik je, kad je Nadbiskup svršio, odgovorio, da želi u svemu ići na ruku Katoličkoj Crkvi. Rekao je da će istrijebiti starokatoličku sektu, koja nije drugo nego društvo za rastavu žena. Rekao je nadalje da neće biti tolerantan prema srpskopravoslavnoj Crkvi, jer to za njega nije Crkva nego politička organizacija.

Iz svega je Nadbiskup dobio dojam, da je Poglavnik iskreni katolik i da će Crkva imati slobodu u svom djelovanju i ako se Nadbiskup ne podaje iluziji da bi sve moglo ići bez poteškoća."15

- Bili su to prvi dojmovi. Stepinac je iznio tri načelne stvari: prvo, Crkva se ne će miješati u aktivnu politiku, niti će, naravno, dopustiti da se država miješa u crkvene stvari /kao da kaže: mi vama ne ćemo imenovati župane, a vi nama ne ćete imenovati župnike, što je Pavelić upravo htio u župi Sv. Marka/; drugo, zahtijeva da se poštuje katolička tradicija i očekuje slobodu za Crkvu i njezino djelovanje. Treće, Pavelić je rekao da će dati slobodu Crkvi, ali da ne će biti tolerantan prema starokatolicima i SPC-u koju ne smatra Crkvom nego "političkom organizacijom". Ali već nakon mjesec dana nastupila je kruta stvarnost i novi vlastodršci počeli su pokazivati svoje pravo lice: Nadbiskup je jasno vidio kako su iluzije nadjačale pozitivna obećanja.

Tajnik, koji je u 15 redaka zabilježio 15-minutni razgovor, i to 12 dana nakon susreta, nije zapisao Nadbiskupovu tadašnju reakciju na Poglavnikov osvrt na starokatolike i pravoslavce u NDH. Ne znamo kako je na to Nadbiskup reagirao. Ako je stekao dojam da je Pavelić "iskreni katolik", mogao je zaključiti da će se držati "katoličkoga morala", na koji ga je inače nerijetko podsjećao, i da ne će provesti istrjebljenje starokatolika, odnosno da "netolerantnost" prema "srpsko-pravoslavnoj crkvi" ne znači sam progon. Stepinac, i sam sumnjičav "da bi sve moglo ići bez poteškoća", govori o katoličkim tradicijama i načelima za koja je stekao dojam da će ih se držati i "iskreni katolik" Pavelić. ${ }^{16}$

15 A. Stepinac, Dnevnik, sv. IV., nakon vijesti: "Hrv. Narod", 27. IV. 1941., str. 204: ("Zvjerstva četnika u Derventi") napisan je gornji tekst na str. 205, dakle najmanje 12 dana nakon susreta.

16 Poratni komunistički, izrazito srbofilski, anonimni pamflet, BiвLIotekA Društva novinara Hrvatske (!), Tajni dokumenti o odnosima Vatikana i ustaške "NDH", Zagreb, 1952., str. 31, ispuštajući bilješku pod tri točkice o 
Stepinčevo 1. PISMo Paveliću, 25. travnja 1941. - Obaviješten od nekih svećenika iz Bačke, nadbiskup Stepinac moli Pavelića da poduzme "diplomatske mjere" kako bi završile brutalne akcije mađarskih vlasti, "u pitanju Hrvata - Bunjevaca", i nekih svećenika, i političara, i vojnika. ${ }^{17}$

- Ne znamo je li bilo državne intervencije na tu molbu. Nema zapisana odgovora nadbiskupu Stepincu.

Stepinčevo 2. PISMo Paveliću, 14. svibnja 1941. - U Glini je počinjen užasan zločin nad više stotina Srba, na osvit 13. svibnja 1941. Stepinac je sutradan uputio Paveliću prosvjed ovoga sadržaja:

"Ovaj čas primio sam vijest, da su ustaše u Glini postrijeljali bez suda i istrage 260 Srba. Ja znam, da su Srbi počinili teških zločina u našoj domovini u ovih dvadeset godina vladanja. Ali smatram ipak svojom biskupskom dužnošću, da podignem glas i kažem, da ovo po katoličkom moralu nije dozvoljeno, pa Vas molim, da poduzmete najhitnije mjere, na cijelom teritoriju Nezavisne Države Hrvatske, da se ne ubije nijedan Srbin, ako mu se ne dokaže krivnja radi koje je zaslužio smrt. Inače mi ne možemo računati na blagoslov neba, bez kojega moramo propasti. Nadam se, da mi nećete zamjeriti ovu otvorenu riječ. Sa odličnim štovanjem." ${ }^{18}$

- Ovdje Stepinac razgovijetno opominje Pavelića da je taj zločin u nebo vapijući grijeh, da je "ovo po katoličkom moralu" nedopustivo, traži "da se ne ubije nijedan Srbin", kojemu se ne dokaže krivnja kojom zaslužuje smrt. I nastavi li se tako, ne će biti blagoslova, nego propast! Ovo je katoličko pa prema tomu i naravno načelo i s obzirom na Srbe i na

Stepinčevoj izjavi "da su Srbi počinili teških zločina u našoj domovini u ovih dvadeset godina vladanja", prigovara Nadbiskupu da "spontano želi jednom razbojniku (i sudom uglavljenom ubici [sud u Beogradu 17. VII. 1929.]) 'božji blagoslov u radu" te da je čuo "brutalne izjave Pavelićeve o drugim crkvama, a osobito vrlo značajnu izjavu, da - ne će biti tolerantan prema srpsko-pravoslavnoj crkvi" i da "ne reagira ni pred Pavelićem a niti intimno u svom dnevniku, nekim negodovanjem ili kritikom takva stava".

17 J. BATELJA, BAS, II., str. 118-119.

18 A. Benigar, nav. dj., str. 404; J. BAtelja, BAS, II., str. 123-124. Dvije se verzije razlikuju u interpunkciji i ponekom malom-velikom slovu. Verzija pisma u: Službeni vjesnik Nadbiskupije zagrebačke (SVNZ), XXXII./1945., sv. 4, 6. studenoga 1945., uz to što je kraćena, razlikuje se od ovdje donesene u nekim formulacijama. 
svakoga čovjeka, jasno napisano, makar se ne ponavljalo svaki dan. Nije bilo nikakva zapisana ili objavljena odgovora Stepincu. Kao da je Poglavniku bilo krivo što je Nadbiskup uopće intervenirao.

O manipulacijskoj historiografiji o pokolju u Glini te 1941. kritički se osvrnuo Glas Koncila u 14 nastavaka $2006 .{ }^{19} \mathrm{Uz}$ užasnu istinu vezane su još užasnije neistine, fantazije, manipulacije i višestruke multiplikacije žrtava!

\section{Stepinčevo 3. PISMo Paveliću, posredstvom Zakonodavnoga povje-} renstva pri Poglavniku, 16. lipnja 1941. - Nadbiskup Stepinac kao predsjednik BK izravno moli predsjednika Zakonodavnoga povjerenstva, dr. Milovana Žanića, a ako on smatra potrebnim, neka izvijesti "i Poglavnika" o nekoliko stvari:

Hrvatski je narod u velikoj većini rimokatoličke vjere i toj vjeri kroz povijest zahvaljuje "da je mogao sačuvati svoj narodni značaj i održati svoju narodnu individualnost u najtežim vremenima".

U bivšoj Jugoslaviji Katolička je Crkva bila trn u oku državnoj vlasti, kojom je premoćno i javno, a još više iza zastora upravljala SPC sa svojim predstavnicima, tako da je kroz 25 godina KC vodila "tešku borbu za osnovna prava i opstanak zajedno sa svojim hrvatskim narodom".

Sada u NDH vlasti jamče čak"i Ustaška načela, koja prožimaju vjernost i odanost svetoj vjeri, a i svečane izjave Poglavnika da će u Hrvatskoj vladati harmonija između države i Katoličke crkve". To može osobito doći do izražaja sada kada se radi o zakonskim odredbama koje se tiču vjere i ćudoređa, Crkve i crkvenih službenika. Na primjer: "Zakon o vjerskim prijelazima, ženidbenoj zabrani rasno mješovitih brakova, o kažnjavanju pometnuća, o radnoj službi omladine itd." Bilo bi u interesu ne samo Crkve, nego u prvom redu i NDH i hrvatskoga naroda da se ti nacrti, "makar neslužbeno i kratkim povjerljivim putem", priopće zakonitom predstavništvu Katoličke Crkve u nas u svrhu da ono stavi "svoje možebitne primjedbe i sugestije".

Nadbiskup ne traži za Crkvu nikakvo "pravo prigovora ili veta niti pravo sudjelovanja u državnom zakonodavnom povjerenstvu", nego uljudno moli "samo to da se bezobvezno ispita u pitanjima koja se tiču Katoličke crkve i njezinih životnih interesa", kakvo stajalište zastupa

19 Tomislav Vuković, "'Pokolj u pravoslavnoj crkvi u Glini' - povijesni događaj ili mit?", u: Glas Koncila, od 27. kolovoza do Božića 2006., brojevi: 35-52. 
Crkva i kakve bi primjedbe stavila takvim nacrtima. A stvar je državne vlasti hoće li i koliko će "voditi računa o tim primjedbama". ${ }^{20}$

- Stepinac ne samo da nije dočekao odgovora, nego je Poglavnik dokinuo Zakonodavno povjerenstvo i rekao ministru Žaniću, koji mu je dolazio sa zakonskim nacrtima: "Pa kako ću ja vladati, ako ćeš mi ti vezati ruke zakonima?"21 Pavelić je očito želio vladati kao apsolutni bez-zakonik! A svaka njegova i primisao na katoličku vjeru, "i u Ustaškim načelima", bila je otrcana floskula i fraza! Unatoč svemu, nadbiskup je Stepinac nastavio pisati i posjećivati Poglavnika makar bilo toliko bezizgledno kao da sv. Petar dođe caru Neronu na Palatin da ga zamoli da u zakonodavstvo unese zakon o zaštiti kršćanske manjine u Rimu! Eto kolik je u tome bio Stepinčev utjecaj na Pavelića!

Srpska Pravoslavna Crkva pokazala je koliko je "premoćno i javno, a još više iza zastora" - riječi su Nadbiskupove Nunciju 1940. - upravljala državnim vlastima kada je 1937. svojim prijetnjama anatemâ i demonstracijama uspjela srušiti već potpisan (1935.) Konkordat sa Svetom Stolicom!

Stepinčev drugi suSRet s Pavelićem, 26. lipnja 1941. - Nakon uspostave Hrvatske biskupske konferencije i njezina prvoga zasjedanja, 25. i 26. lipnja 1941. u Zagrebu, skupina biskupa pohodila je 26. lipnja poglavnika Pavelića s nadbiskupom Stepincem na čelu. U svom je govoru Stepinac kao predsjednik BK rekao da nema sukoba između pravoga domoljublja i pravoga bogoljublja te nastavio: "Ta svijest dovodi nas danas pred Vas, da Vas kao legitimni predstavnici Crkve Božje u Nezavisnoj Državi Hrvatskoj od srca pozdravimo kao njezina državnog poglavara s obećanjem iskrene i lojalne suradnje za bolju budućnost naše domovine." I ujedno upozorio: "Ako bismo kada, dakle, i morali po pastirskoj dužnosti reći otvorenu riječ, bu-

20 J. Batelja, BAS, II., str. 149-151; Isti, Rivellijeva zavjera laži, Blaženi Alojzije Stepinac i Srpska Pravoslavna Crkva, Postulatura blaženog Alojzija Stepinca, Zagreb, ${ }^{2} 2015$., str. 249-250, 260.

21 Vilim Cecelja, "Moja sjećanja na uz. kard. Stepinca", tipkopis kod A. BeniGARA, Alojzije Stepinac, str. 367. Ta je sjećanja vlč. Cecelja poslao uredniku Hrvatske revije da ih objavi nakon njegove smrti (umro je 3. srpnja 1989.), što je i objavljeno pod naslovom: "Moja sjećanja na uzoritoga kardinala Stepinca zagrebačkoga nadbiskupa", u: Hrvatska revija, München - Barcelona, 4/1990., str. 690-737. Događaj prikazan na str. 728. 
dite uvjereni, da nitko više od katoličkog biskupa ne nosi na umu opomenu sv. Apostola: 'Sve poštujte, braću ljubite, Boga se bojte, kralja štujte!' (1 Pt 2,17)." I zaželio mu: da ga Otac svjetlila "obdari onim duhom, koji je glavaru države potreban, da svojim narodom upravlja 'in justitia et veritate - u pravdi i istini', kao najčvršćem temelju Bogom blagoslovljene budućnosti". ${ }^{22}$

- Poglavniku je jasno dano na znanje da ne može očekivati biskupsku suradnju i lojalnost u državnim nepravdama i neistinama! Nije bila šutnja nego govor kakav se rijetko čuje!

Stepinac priopćuje svećenstvu Pavelićevu zakonsku odredbu, 27. lipnja 1941. - Pavelić je istoga dana kada su hrvatski biskupi bili kod njega datirao "Izvanrednu zakonsku odredbu i zapovijed" da bi, prema glasinama, 28. lipnja započeli progoni protiv dijela pučanstva. Stoga Poglavnik odlučuje i određuje:

tko takve glasine širi, bit će stavljen pred prijeki sud;

tko izvrši bilo kakvo nasilje nad životom ili imovinom bilo kojega državljanina ili pripadnika NDH, bit će stavljen pred prijeki sud;

svi dužnosnici ustaških organizacija i svi zapovjednici osobno su odgovorni za svaki takav izgred;

svaki ustaški član, koji bi nešto takvo počinio, ima biti strijeljan;

ako bi se pojavili četnici ili ostatci srpske vojske, vlasti su dužne upotrijebiti hladno i vatreno oružje u obrani;

upozorava da će provesti lustraciju u hrvatskom društvu;

tko smatra da je povrijeđen zakon ili njegov probitak, neka to prijavi mjerodavnoj vlasti.

I točka, koja se po Benigaru odnosi na Stepinca: "...pozivam sve i svakoga da se okani bilo kakove intervencije kod bilo koje državne ili slične vlasti u osobnim kao i u materijalnim predmetima, jer će se svaka intervencija smatrati sabotažom i postupati će se po propisima prijekoga suda". ${ }^{23}$

22 A. Benigar, nav. dj., str. 390.

23 A. Benigar, nav. dj., str. 405-406. Cjelovita Pavelićeva Izvanredna zakonska odredba i zapovijed u: J. BATELJA, BAS, II., str. 153-155. 
- Unatoč tomu, Nadbiskup je tu državnu izvanrednu zakonsku odredbu razaslao kleru svoje nadbiskupije i zatražio da se pročita u crkvi pred narodom. ${ }^{24}$ Stepinac nije ni shvatio ni prihvatio da se riječ "sabotaža" odnosi na njega, pa je on i dalje svjesno i hrabro kontaktirao državne vlasti.

Stepinčev treći susReT s Pavelićem, nakon 29. lipnja 1941. - Episkop bački Irinej Ćirić obratio se 29. lipnja 1941. nadbiskupu Stepincu moleći ga da se zauzme za njegova brata Stevana [ministar prosvjete Kraljevine Jugoslavije 1934.-1935. i 1939.], koji je, bolestan, odveden "iz postelje u internaciju u Koprivnicu, gde nema uslova za lečenje".

Nadbiskup je Stepinac za vrijeme svoga procesa osobno napisao o tome izjavu koja je ovjerena na Duhovnom stolu 1. listopada 1946., a glasi:

"Episkop pravoslavni Irinej Ćirić obratio se na mene pismeno, da mu ishodim oslobođenje brata Stevana Ćirića, bivšeg ministra, kojeg su ustaše odveli u logor u Koprivnicu, a bolestan je. Pismo je došlo iz Mađarske iz Novog Sada. Odgovor se nije mogao poslati.

Ali sam otišao u stvari Stevana Ćirića osobno do Poglavnika i zamolio ga, da toga čovjeka pusti na slobodu, jer je bio vrijedan i sklon nama Hrvatima, makar je bio Srbin.

Poglavnik nažalost nije bio odviše sklon da popusti. Na koncu mi je rekao, da će ga dati otpremiti u Srbiju. Rekao sam, bolje i to, nego da pogine u logoru.

Kasnije nisam više ništa doznao, kako je ta stvar svršila.

Izgleda da je Ćirić prebačen u Srbiju."25

Oslobođen je i živio do 24. svibnja 1955. u Srijemskim Karlovcima.

- Iako je Stepincu bilo zaprijećeno da će mu se intervencija smatrati "sabotažom", on je i dalje intervenirao kod državnih vlasti, pa i kod Pavelića, kada je primio provjerene vijesti, a ne "glasine".

24 J. BATELJA, BAS, II., str. 155.

25 J. BAtelja, BAS, II., Irinejevo pismo: str. 182. Stepinčeva bilješka: str. 190; faksimil: Isti, Rivellijeva zavjera laži, slika VIII.; talijanski prijevod pisma: Fiorello Cavalli, Il processo dell'Arcivescovo, Rim, 1947., str. 245-246. 
Stepinčevo 4. PISmo Paveliću, 21. srpnja 1941. - Nadbiskup piše Poglavniku povodom nečovječna postupanja prema Srbima i Židovima prigodom deportiranja u sabirne logore i u samim logorima:

"Poglavniče! Slobodan sam kao nadbiskup i zastupnik katoličke Crkve skrenuti Vašu pažnju na neke pojave, koje me bolno diraju. Pripominjem odmah, da sam uvjeren, te se ove pojave dešavaju bez Vašega znanja, a da će se jedva tko naći, da Vas na njih upozori, pa da mi je to više dužnost, da ja to učinim.

Čujem s više strana, da se tu i tamo nečovječno i okrutno postupa sa Srbima i Židovima prigodom deportiranja u sabirne logore, a i u samim logorima; što više da od takva postupka nisu izuzeta ni djeca, ni starci ni bolesnici!"

I onda Nadbiskup ističe općenito: "odnosne mjere, koje se u tom smjeru provode, mogle bi se provoditi, a da postignu potpuni učinak, na humani i obzirniji način tako da se u čovjeku zaista gleda čovjeka i sliku Božju, osobito da se pokaže ljudski i kršćanski obzir prema slabim starcima i staricama, nejakoj i nedužnoj djeci i prema bolesnicima".

A potom prelazi na pet pojedinačnih stvari:

a) da deportirani mogu spremiti "najnužnije stvari" i srediti "obveze prema obitelji i prema službi";

b) da se deportiranje ne vrši "u prenatrpanim plombiranim vagonima";

c) da se deportircima "daje dovoljno hrane";

d) da se "bolesnima omogući liječnička njega";

e) da im se dopusti dopremanje "najnužnije hrane i omogući dopisivanje s obitelji".

Konačno, Nadbiskup se zauzima za katolike konvertite i traži da se prema njima primijene takve mjere da mogu obavljati svoje vjerske dužnosti. ${ }^{26}$

- Na ovaj će Stepinčev glas stići nekakav odgovor nakon tjedan dana. O tome poslije. 
Stepinčevo 5. PISMo Paveliću, 26. srpnja 1941. - Beogradski nadbiskup Josip Ujčić obraća se nadbiskupu Stepincu 24. srpnja 1941. prenoseći mu svoje razgovore s ponekim pravoslavnim episkopom i vjernicima, a tiču se stanja pravoslavnih u Hrvatskoj. Tuži se konkretno:

da "su Srbi nezadovoljni";

da se počelo govoriti kako se "sve to dešava connivente [convivente, consentiente - uz pristanak] Sede Apostolica";

da "ima toliko nevine krvi, - jer često stradavaju osobe, koje lično nijesu ništa sagriješile";

da "u Srbiji raste neraspoloženje protiv katolika" i da bi oni mogli platiti "račun" zbog zla koje su počinili "neki ljudi u Hrvatskoj";

da su Nijemci, pogotovo Talijani, neraspoloženi "radi nehumanog postupka, što se prakticira u Hrvatskoj sa Srbima";

"da je hrvatski narod izgubio mnoge simpatije, da je u zadnje doba mnogo trpio na ugledu".

"Neka pokaže hrvatski narod u jubilarnoj godini, da je doista narod kršćanske kulture, narod ljubavi i pravde... inače što će misliti Sveta Stolica o nama Hrvatima."27

Prijepis toga pisma Stepinac je, sa svojim popratnim dopisom od 26. srpnja $1941 .{ }^{28}$ proslijedio Paveliću na znanje i ravnanje, odnosno neka njegove službe provjere jesu li to "glasine" ili prolijevanje "nevine krvi". Ni na taj intervent nije bilo zabilježena odgovora. Ali ne može se blaženoga Stepinca optužiti da je "uglavnom ćutao"!

Pavelićev posredan odgovor Stepincu, 28. srpnja 1941. - Na Stepinčevo gore navedeno pismo o postupcima prema Srbima i Židovima, od 21. srpnja, na Pavelićevu adresu, stigao je iz njegova ureda posredan odgovor ovoga sadržaja:

27 J. BATELJA, BAS, II., str. 174-176.

28 J. BATELJA, BAS, II., str. 177. 


\section{"MinistarstVu PRAVOSUĐA I BOGoŠTOVLJA}

Dostavlja se priloženi dopis nadbiskupa Alojzija Stepinca, u pogledu postupka sa Židovima i Srbima, time da se istome odgovori, da informacije, koje isti navodi ne odgovaraju istini.

U Zagrebu, dne 28. srpnja 1941. Prilog 1."29

Ministarstvo prenosi nadbiskupu Stepincu sutradan, 29. srpnja, da se njegove "informacije osnivaju na obavjestima (sic!) koje su bez ikakova temelja". ${ }^{30}$ Dakle "glasine"!

U odgovoru se ne navodi pismo nadbiskupa Ujčića, od 24. srpnja, koje je nadbiskup Stepinac poslao Paveliću 26. srpnja i koje je moglo prispjeti do 28. srpnja kada je reagirao Pavelićev ured.

- Ovakav diktatorski odgovor i Poglavnika i ministarstva nije se očekivao. A kako bi bilo na čast hrvatskim glavešinama, u prvom redu Poglavniku, da je upozorenje ozbiljno shvaćeno, a ne kao lažne glasine! Blaženi će Stepinac nerijetko doživjeti da je njegov vapaj toliko puta ostao glas vapijućega u pustinji, ali je bio glas, glas koji je svemogući Bog čuo, čuo ga je i Poglavnik, a mogao ga je čitati i Patrijarh 2010., četiri godine prije nego je optužio nadbiskupa Stepinca pred Papom 2014. godine zbog šutnje!

Stepinac ne dopušta podložnost Crkve državi, 4. kolovoza 1941. Tajnik Apostolskoga vizitatora u NDH don Ramira Marconea, don Giuseppe Masucci, u svoj je dnevnik 4. kolovoza 1941. upisao: "Nadbiskup Stepinac prikazuje iskreno položaj u Hrvatskoj. On oštro osuđuje namjere, da se Crkva podloži državi. Ističe, da je velik rodoljub, ali ukazuje $\mathrm{u}$ isto vrijeme na mnoge diktatorske mjere, koje dan za danom postaju sve brojnije i štetne su također za Crkvu."31

- Kao što je bilo vrijeme "šestojanuarske diktature", tako je sada nastupilo vrijeme fašističke, nacističke i ustaške diktature, u kojoj "diktatorske mjere" iz dana u dan postaju "sve brojnije i štete također i Crkvi", koja očito ne surađuje s takvim režimom!

29 J. BATELJA, BAS, II., str. 178-179.

30 J. Batelja, BAS, II., str. 181.

31 Giuseppe Masucci, Misija u Hrvatskoj, Madrid, 1967., str. 32. 
Stepinčevo 6. PISMo Paveliću, 3. listopada 1941. - Nadbiskup se izravno obraća na Poglavnika predstavljajući mu problem protjeranih trapista iz Slovenije, iz Rajhenburga, i privremeno nastanjenih u "Mariji Zvijezdi" kod Banje Luke. Protjerali su ih Nijemci pod optužbom da su surađivali s partizanima. Nadbiskup uljudno moli Poglavnika da se tih 30 redovnika "smjeste u ovoj nadbiskupiji i da budu tako u duhovnu i privrednu korist nadbiskupiji i u blagodat čitave Nezavisne Države Hrvatske". Stepinac sugerira: "Možda bi im se mogao dati srpski samostan u Orahovici (nekad samostan naših Pavlina)."32

- Svi su trapisti ostali u Banjoj Luci, a na svršetku rata vratili su se u Rajhenburg, gdje su im partizani sve nacionalizirali 1947. "Stojković [...] pominje i pismo Stepinca Paveliću u kome traži da se pravoslavni manastir Orahovica, iz koga su srpski kaluđeri proterani ili pobijeni, preda na upotrebu katoličkom monaštvu." ${ }^{33}$

$\mathrm{Na}$ taj je prigovor Nadbiskup odgovorio već na sudu 3. listopada 1946.: "Gospodin mi je predsjednik predočio prijepis, što sam tražio prazni pravoslavni manastir - nekoć naš pavlinski - u Orehovici, da se u nj smjeste trapisti, koje su Nijemci protjerali iz Rajhenburga. Smatram, da mi je bila dužnost, da pomognem braći Slovencima, koji su od Hitlerovaca bili izagnani, da se sklone."34

Stepinčevo 7. PISMo Paveliću, 20. studenoga 1941. - U Zagrebu su 17. i 18. studenoga 1941. održane biskupske konferencije Hrvatskoga katoličkog episkopata, na kojima se razmatralo stanje u državi u vezi s prijelazima pravoslavnih vjernika na katolicizam. Saslušana su brojna svjedočanstva pojedinih članova Hrvatskoga episkopata o teškim zloporabama na terenu, a četvorica biskupa poslala su i svoja pisana izvješća: biskup banjolučki Jozo Garić, 4. studenoga; mostar-

32 Fotokopija pisma objavljena: Embassy of the Federal Peoples Republic of Yugoslavia, The Case of Archbishop Stepinac, Washington, 1947., str. 8081; citat: str. 81, Predgovor napisao Sava Kosanović, ambasador; J. BATELJA, BAS, II., str. 199-200.

33 Anja Filimonova - Vladimir Dimitrijević (prir.), Kanonizacija Alojzija Stepinca. Izazovi i odgovori, Fond strateške kulture, Moskva - Bernar, Beograd, 2016., str. 21.

34 A. Benigar, nav. dj., str. 583; M. ŠKalić-ŠTAmbuk, nav. dj., str. 90; Juraj Batelja (prir.), Blaženi Alojzije Stepinac, Propovijedi, govori, poruke 1941.-1946., vidi osobito str. 512 i str. 518. 
ski biskup Alojzije Mišić, 18. kolovoza i 7. studenoga; vrhbosanski nadbiskup Ivan Sarić, 15. studenoga, te kotorski biskup i dubrovački apostolski upravitelj Pavao Butorac, 4. studenoga 1941. Biskupi su sastavili 10 načelnih točaka, dogmatskih i kanonskih pravila, po kojima se moraju ravnati takvi prijelazi. Izabrali su trojicu svojih članova kao Odbor: Alojzije Stepinac, predsjednik; senjski biskup Viktor Burić i križevački administrator Janko Šimrak. A u Izvršni odbor imenovali su petoricu svećenika: Franju Hermana, Augustina Juretića, Janka Kalaja, Nikolu Borića i Krunoslava Draganovića. Stepinac je dva dana poslije toga uputio opširan memorandum Paveliću na znanje i ravnanje.

Budući da su "prijelazi" tema za sebe, prenosimo samo zaključak toga pisma:

"Poglavniče! - Nitko ne može poricati, da su se dogodila strašna nasilja i okrutnosti, jer ste Vi, Poglavniče, sami javno osudili nasilja raznih nazovi Ustaša, što više dali i strijeljati zbog izvršenih zločina. Zaslužuje svako priznanje Vaša odlučnost, da u zemlji vlada pravda i red.

Hrvatski se je narod ponosio do sada svojom tisućljetnom kulturom i kršćanskom uljudbom. Stoga smo očekivali, da će ju u praksi pokazati, sada, kad je došao do svoje slobode, da će biti plemenitiji i čovječniji nego oni, koji su do jučer vladali njime.

Crkva mora sa stanovišta evanđelja osuditi zločinstva i ispade neodgovornih elemenata i nezrelih mladića te zahtijevat i puno poštovanje čovječje ličnosti bez obzira na dob, spol, vjeru, narodnost ili rasu, jer su svi ljudi djeca Božja i za sve je umro Krist - 'qui vult omnes homines salvos fieri' [koji želi sve ljude spasiti - 1 Tim 2,4].

Vjerujemo, Poglavniče, da dijelite isto mišljenje s nama i da ćete učiniti, što je u Vašoj moći, da se obuzda nasilje pojedinaca i da u zemlji upravlja i vlada samo odgovorna vlast. U protivnom slučaju iluzoran je svaki rad na konverziji skizmatizma." ${ }^{35}$

- Nema nikakva pisana i objavljena odgovora na ovaj vapaj i priziv na pravdu i red. Stepinac ističe da je nužno poštovati ljudsku osobu "bez obzira na dob, spol, vjeru, narodnost ili rasu, jer su svi ljudi djeca Božja i za sve je umro Krist" te dodaje: ako se nasilja nastave, uzaludan je rad na prijelazima s pravoslavlja ili skizme, o kojima je Crkva dala svoja načela, u skladu sa smjernicama Svete Stolice. Ri-

35 J. BAtelJa, BAS, II., str. 224-233; talijanski: F. CAVAlli, nav. dj., str. 210-229. 
ječ "skizma", "skizmatizam" ili raskolništvo, koje praktično traje od 1054. do 1964., u kontekstu je ondašnje terminologije i teologije i ne možemo iz Stepinčeva pera očekivati nazivlje iz koncilskoga dekreta o jedinstvu kršćana Unitatis redintegratio iz 1964. godine!

Stepinčevo 8. PISMo Paveliću, 29. studenoga 1941. - Nadbiskup se zalaže za prognane: "Radi se o slovenskim doseljenicima, koji su morali tečajem prošlih ljetnih mjeseci ostaviti svoje domove i sve, što su imali i posjedovali, te su bili, među ostalim, odpremljeni i u razne kotare NDH; ima ih danas oko 10.000, koji živu raštrkani posvuda od Varaždina do Mostara i Sarajeva, od Šida do Ključa i Slunja. Njihova je sudbina vrlo teška, često upravo nepodnosiva." Nadbiskup se zauzima za njih, moli smještaj, hranu, posao i kao predsjednik Biskupskih konferencija. O tome su biskupi raspravljali i na konferencijama u Zagrebu, u studenome $1941 .{ }^{36}$

- Pavelićev odgovor nije registriran. A što se Stepinac prema Paveliću odnosi kulturnije i obzirnije, to se Pavelić prema Stepincu odnosi nekulturnije i bezobzirnije. Neka i slijepi vide i gluhi čuju da su to dva različita postupka i stajališta, a ne dva "kolaboratora", a pogotovo da Stepinac nije "uglavnom ćutao"!

Stepinčevo 9. PISMo Paveliću, 6. prosinca 1941. - Nadbiskup i predsjednik HBK obraća se Paveliću moleći ga da se omogući da djelatnici Karitasa pohode za Božić sirotinju i bijednike, napose vjernike koji su smješteni po logorima u Jasenovcu i Loboru. "Ja Vas, Poglavniče, uljudno molim, za obavijest o toj stvari što skoriju, jer je Božić pred vratima već, a treba prilično vremena, da se pomoć kako tako organizira." ${ }^{37}$

- Nije zabilježena povratna informacija na taj razumni katolički glas. $\mathrm{Ni}$ u jednom dosadašnjem pismu Stepinac ne zahvaljuje na eventualno iskazanoj Pavelićevoj usluzi. A to Nadbiskup sigurno ne bi propustio učiniti da je imao na čemu. A to ujedno znači da nadbiskup Stepinac nije šutio pokraj tolike sirotinje i bijede!

36 J. BATELJA, BAS, II., str. 241-243.

37 J. BATELJA, BAS, II., str. 247-248; faksimil pisma: Isti, Rivellijeva zavjera laži, str. X; talijanski prijevod: F. CAVALLI, nav. dj., str. 263-264. 
Stepinčev četvrti suSRET s Pavelićem, 31. prosinca 1941. - Primivši od beogradskoga nadbiskupa msgr. Josipa Ujčića pismo, od 29. prosinca 1941., kojim se zauzima za gornjokarlovačkoga episkopa Savu Trlajića, "navodno u Lepoglavi (?), ili u kojem drugom logoru" - piše Ujčić moleći Stepinčevu intervenciju, a nadbiskup Stepinac odmah odgovara nadbiskupu Ujčiću, 31. prosinca: "Osobno sam intervenirao kod Poglavnika zajedno s legatom Sv. Stolice Marconeom. Dobili smo odgovor, da toga nema u Lepoglavi. Što smo mogli?"38

- Bila je to izvrsna prilika da se Poglavnik pokaže dobrohotnim vladarom pred dvojicom najuglednijih čestitara Nove godine amnestirajući episkopa Savu ako je i u čemu bio kriv, ali on onako. Ovo je drugi put da Pavelić uzvraća da nije istina što mu Stepinac govori i piše. A Nadbiskup sigurno nije iznio što nije bilo potpisano i ovjereno kao sigurna vijest. Bilo bi na čast Eparhiji gornjoj karlovačkoj da na njezinu portalu u životopisu "Sv. Save Gornjokarlovačkoga" čitamo i vijest da su se za njega zauzimala i dvojica katoličkih nadbiskupa! ${ }^{19}$

Stepinčevo 10. PISMo Paveliću, 8. veljače 1942. - Nadbiskup prosvjeduje kod Poglavnika zbog upletanja Talijana, osobito Nijemaca, u život hrvatskoga naroda. "Moram naglasiti, da ih se ja baš ništa ne bojim, ali možda ne bi bilo loše, Poglavniče, da naše vlasti malo pripaze na njihovo djelovanje i pokažu više energije. Jer ako imadu oni svoj Lebensraum [životni prostor], Bog ga je dao i Hrvatskom narodu. ${ }^{140}$

- I na ovaj je prosvjed Pavelić odšutio! Stepinac se osvrće na ovakve događaje u zatočeništvu u Krašiću 1954.: "Kasnije sam poslije tolikih nemilih ispada po dužnosti morao istupiti i napasti i osuditi neka djela ustaša i Nijemaca. Onda su mi predbacili, da rušimo hrvatsku državu. Nisam se time dao smesti i danas vidim, da se nisam prevario."41

Stepinčevo 11. PISMo Paveliću, 8. veljače 1942. - Nadbiskup odlučno prosvjeduje u pismu Poglavniku zbog uključenja svećenika u politiku, tj. u Hrvatski sabor, pozivajući se na svoje okružnice iz 1935. i 1938., u kojima je pod prijetnjom sankcija zabranio svećenicima

\footnotetext{
38 A. Benigar, nav. dj., str. 408; J. BAtelja, BAS, II., str. 256.

39 http://eparhija-gornjokarlovacka.hr/Episkop-Trlajic-L.htm (5. 11. 2016.).

40 J. Batelja, BAS, II., str. 280-281; talijanski: F. Cavalli, nav. dj., str. 192-196.

41 J. VRaneković, Dnevnik, pod nadnevkom 3. veljače 1954., str. 262.
} 
kandidiranje u političkim strankama: "Ja, Poglavniče, moram stajati i danas na tom stajalištu, uoči otvorenja Hrvatskoga Sabora. Za ono malo [koristi], koju donesu svećenici političari, ne isplati se nanijeti dvaput više štete i Crkvi i domovini, zanemarivanjem svećeničkih dužnosti, bili ti svećenici pripadnici HSS ili ustaškog pokreta."42

- Na ovo pismo stigao je odgovor župana pri Poglavniku po Pavelićevoj naredbi, 19. veljače, koji piše da nije on, Pavelić, nego predsjednik vrhovnoga suda postavio svećenike za narodne zastupnike. Nije šija, nego vrat! I na kraju kaže da nije razumljiva ona stavka u pismu da "svećenik ne može danas primati na sebe odgovornost za političke čine". ${ }^{43}$

- Loš primjer Pavelićeve zloporabe klera u političke svrhe, a dobar primjer Stepinčeva odnosa prema državnim vlastima u zabrani svećenicima da se miješaju u aktivnu politiku, što je Nadbiskup u prvom susretu jasno rekao Poglavniku 16. travnja 1941. Ne odgovara apsolutno činjenici Patrijarhova optužba da je Stepinac "uglavnom ćutao". Takvo pisanje nije više obična optužba nego kleveta, i to pred Papom!

Stepinčev peti suSRet s Pavelićem, 23. veljače 1942. - Stepinac je pozdravio Pavelića na pragu saborne crkve sv. Marka u Zagrebu kratkim govorom, 23. veljače 1942., prije otvorenja Hrvatskoga sabora. Temeljna je Nadbiskupova poruka bila:

"Neka [Hrvatski sabor] donosi zakone poštene, koji se neće kositi sa zakonom Božjim, da se osigura blagoslov Boga Stvoritelja. Jer je pisano: 'Jedan je zakonodavac i sudac, koji može spasiti i upropastiti.' (Jak 4,12). Neka donosi zakone pravedne: gdje su jednaki tereti, neka su jednaka i prava! Neka donosi zakone moguće, da se narodu ne navaljuju tereti, kojih ne može podnositi." Stepinac nastavlja: "Poglavniče! Obnova Hrvatskog sabora dokazom je Vaše duboke i žive svijesti odgovornosti, koji golemi teret želite podijeliti sa svojim suradnicima. I tu molitvu prati molitva Crkve i naših srdaca: neka Vječni Sudac, koji upravlja udesima naroda, svojom svemoćnom desnicom uzida u temelje Hrvatskoga sabora i ureže u srce sviju Vaših suradnika isto tako duboku živu svijest odgovornosti, da mogu Vas,

42 M. ŠKalić-ŠTAmbuk, nav. dj., str. 119-120; J. BATELJA, BAS, II., str. 282-283, cijelo pismo: str. 281-283.

43 J. BAtelja, BAS, II., str. 287-288. 
Glavara Nezavisne Države Hrvatske, uspješno pomagati u obnovi i podizanju drage nam Domovine na vječnim temeljima evanđeoskih Kristovih načela!"44

- Ključne riječi: poštenje, pravda, zakon, isti tereti - ista prava, svijest odgovornosti, suradnja, Božji sud, molitva, blagoslov. Reakcija na taj crkveni govor nadbiskupa Stepinca bila je ta da je Pavelić - prema riječima Marka Došena, predsjednika Sabora - rekao da ga "ovaj balavac ne će učiti politiku".45 Odnosno prema drugima: "Zar misli Nadbiskup, da će meni dijeliti lekcije?"' ${ }^{\prime 6} \mathrm{Ni}$ godinu dana nakon prvoga susreta sa Stepincem, Pavelić je pokazao koliko je "iskreni katolik", kako se bio prvi put predstavio, i koliko je njemu stalo i do hrvatskoga naroda i do hrvatske države! Ovo nije više oholo ignoriranje, nego škandalozno vrijeđanje.

Stepinčevo 12. PISMo Paveliću, 26. svibnja 1942. - Očuvan je koncept pisma koje je Stepinac uputio Paveliću u povodu navodnoga iseljenja pravoslavnoga pučanstva s Korduna: "Nadam se, Poglavniče, da ćete učiniti sve, da se ne povrijedi zakon Božji i da će djeca biti potpuno zaštićena. ${ }^{47}$

- Ne znamo što je bilo s izvornim pismom i eventualnom povratnom obaviješću.

Stepinčev šesti suSRET s Pavelićem, 17. rujna 1942. - Stepinac zapisuje da je spomenutoga dana intervenirao kod Poglavnika za vjernike iz Pakraca koji su prešli na katoličku vjeru, a optuženi za kontakte s odmetnicima u šumi i potom odvedeni u logor kao taoci. Nadbiskup moli upravu logora u Staroj Gradiški da se što hitnije izvrši Poglavnikov nalog o puštanju spomenutih građana na slobodu. ${ }^{48}$ Radilo se o razmjeni 200 talaca za 2 hrvatska državna službenika.

44 J. BATELJA, BAS, II., cio govor: str. 292-293.

45 M. ŠKalić-Štambuk, nav. dj., str. 95, 202; J. BATElJa, BAS, II., str. 292, bilj. 182.

46 V. Cecelja, "Moja sjećanja na uzoritoga kardinala Stepinca, zagrebačkoga nadbiskupa", u: Hrvatska revija, München - Barcelona, 4/1990., str. 720.

47 J. BATELJA, BAS, II., str. 320.

48 A. Benigar, nav. dj., str. 410-411; J. BAtelja, BAS, II., str. 375-376; talijanski: F. CAvalli, nav. dj., str. 240-241. 
- Stepinac je učinio svoju kršćansku i biskupsku dužnost, a u ovom slučaju pretpostavljamo da je bilo koristi od njegove intervencije i kod Poglavnika i u logoru, jer su oba službenika oslobođena.

Stepinčevo 13. PISmo Paveliću, 24. veljače 1943. - Stepinac se "s velikim bolom u duši" obraća Paveliću da dozna za sudbinu sedmorice svojih svećenika koji su odvedeni u Jasenovac. Iz svega što se dogodilo zaključuje "da su svi poubijani". Prosvjeduje što nisu izvedeni na redoviti sud, ili na prijeki sud ili na pokretni prijeki sud. I nastavlja: "Ovo je sramotna ljaga i zločin, koji vapije u nebo za osvetom, kao što je sramotna ljaga čitavi Jasenovac za Nezavisnu Državu Hrvatsku. Poglavniče! Što se mene kao svećenika i biskupa tiče, ja velim sa Kristom na križu - Oče, oprosti im, jer ne znaju što čine!"49

- Ni na ovaj veliki bolni vapaj, kojim je Stepinac nazvao Jasenovac "sramotnom ljagom" za NDH, nije imao nikakva odgovora od Pavelića. Logori su ulazili u ratne mjere i zakone, ali i tu postoje mjere i zakoni. Nije dakle Stepinac "uglavnom ćutao" nego je s Kristom s križa vapio: "Oče, oprosti im jer ne znaju što čine!"

Stepinčevo 14. PISmo Paveliću, 6. ožujka 1943. - Stepinac piše prosvjed Paveliću zbog progona Židova i moli oslobođenje hrvatskih građana iz talijanskih logora.

- diže glas i odlučno otklanja miješanje državne vlasti u pitanje takovih brakova, koji su nerazrješivi, bez obzira na rasnu pripadnost;

- znano je da i na višim vrhovima državne uprave ima brakova koji su zaštićeni [Pavelićeva supruga bila je Židovka, kao i supruga njegova ministra Milana Žanića, ali one su zaštićene!];

- protiv logike je i pravde da jedni budu zaštićeni, a drugi nezaštićeni;

- takve odredbe nisu utemeljene ni u zdravu razumu niti su u skladu s državnim i narodnim interesima;

- moli da se zaštiti najosnovnije životno pravo onih pripadnika Katoličke Crkve, koji su to postali bilo krštenjem bilo prijelazom s pravoslavlja, a kojima se ne može dokazati nikakav osobni zločin protiv državnih probitaka;

49 J. BATElJA, BAS, II., str. 468, bilj. 182. 
- moli da "i od ostalih podanika naše države" nitko nepravedno ne trpi; - u sabirnim logorima ima mnogo njih koji su nedužni i ne zaslužuju tako tešku kaznu;

- ako je posrijedi miješanje "koje strane vlasti u naš unutarnji narodni i politički život, onda se ne bojim, da ovaj moj glas i prosvjed dođe i do organa dotične strane vlasti. Katolička naime Crkva ne pozna nikakova straha pred ikojom zemaljskom silom, ako se radi o obrani najosnovnijih prava čovjeka";

Pismo završava: "Poglavniče! Ne dopustite, da se neodgovorni i nepozvani elementi ogrešuju o istinsko dobro našega naroda. Kršenje naravnog zakona u ime naroda i države osvećuje se na samom narodu i na državi: u zemlji se stvara ogorčenje, koje teži za osvetom, dok vanjski neprijatelj napada etičku našu vriednost." 50

- Ni na ovo pismo nije bilo nikakva odgovora.

Stepinac se zalaže da "i od ostalih podanika naše države itko nepravedno trpi", dakle ni Srbi! Nije to znak šutnje, nego glas prosvjeda.

Stepinčevo 15. PISMo Paveliću, svršetkom ožujka 1943. - Nadbiskup upućuje Poglavniku pismo kojim ga moli da zagrebački Karitas može nesmetano skupljati hranu i otpremati je u Dalmaciju, osobito na otoke Hvarske biskupije. ${ }^{51}$

- Nismo našli odgovora.

Stepinčev sedmi susRet s Pavelićem, u proljeće 1944. - Vlč. Cecelja u razgovoru s hrvatskim provincijalom Družbe Isusove p. Karlom Grimmom iznio je ideju da se Stepinac i Pavelić sastanu i raščiste nesporazume, koji su nastali nakon Nadbiskupove propovijedi na blagdan Krista Kralja, 31. listopada 1943. Do susreta je došlo. Stepinac priča vlč. Cecelji: "Evo, upravo sam došao od Poglavnika! Iznenadio sam se, da je do toga sastanka tako brzo došlo. Mislio sam, da će sastanak biti negdje na Rebru, ali me Poglavnik danas po podne

50 J. Batelja, BAS, II., cijelo pismo: str. 468-470; talijanski prijevod: F. CAVALLI, nav. dj., str. 259-262.

51 J. BAtelja, BAS, II., str. 494-496. Na konceptu pisma dopisano drugom rukom da je primljeno 31. III. 1943. 
telefonski nazvao iz Markova trga i ponudio mi, ako imam vremena, da mogu odmah doći k njemu na razgovor, jer je baš ovaj čas slobodan. Pošao sam odmah. Poglavnik me je primio u svom uredu i započeo je razgovor molbom, neka iznesem sve što mislim, da bi trebali između sebe raščistiti. Uzeo sam svoje opaske i iznio svih 18 točaka, o kojima bismo se trebali porazgovoriti. Poglavnik je mirno saslušao i kad sam svršio, reče mi:

- Preuzvišeni! Ima stanovitih ljudi, koji nemaju drugog posla pa intrigiraju između mene i vas. To je moje mišljenje.

Tim je riječima Pavelić prekinuo svaki daljnji razgovor i otpravio nadbiskupa i razgovor je bio svršen." ${ }^{52}$

- Volio bih doći do tih 18 točaka - među kojima su bile i teme odnosa prema Srbima - a koje mu je Stepinac u oči izgovorio i pokazati ih patrijarhu Irineju da vidi da "kardinal Stepinac" nije "uglavnom ćutao"!

Pavelić prvi, posljednji i jedini put u zagrebačkoj katedrali, 1943. - Stepinčev odvjetnik dr. Ivo Politeo u svom obrambenom govoru kaže da je Pavelić "jedan jedini put prisustvovao službi božjoj u katedrali, i to samo onda kad su Talijani godine 1943. priredili zadušnice za Vojvodu d'Aosta, a i taj jedini put nije ga na ulazu dočekao ni nadbiskup ni nitko od klera, nego samo obični sakristijan?"53

- Iz crkvenih bilježaka i dnevnika nije potvrđena ova vijest, niti je uopće jasno što je posrijedi. Naime Aimone di Savoia-Aosta odrekao se naslova hrvatskoga kralja Tomislava II. nakon pada Italije 8. rujna 1943. (a preuzeo titulu sin mu, rođen u rujnu 1943., Amedeo di Savoia-Aosta, s naslovom Zvonimir II.). Aimoneov otac, također Amedeo, umro je 3. ožujka 1942.

Stepinčevo 16. PISmo Paveliću, 9. veljače 1944. - Nadbiskup se Stepinac zauzima kod Pavelića za preinaku smrtne kazne pukovnika Vladimira Galića i dopukovnika Petra Bakote u lakšu kaznu. "...da služeći se svojom vrhovničkom vlašću, velikodušno oprostite ovoj

52 A. Benigar, nav. dj., str. 484; V. Cecelja, nav. čl., str. 727.

53 M. ŠKalić-ŠTAmbuk, nav. dj., str. 193-194. 
dvojici osuđenika njihovu smrtnu kaznu, i pretvorite je u kojugod drugu pa i najtežu kaznu". ${ }^{54}$

- Iz nekih podataka na internetu vidljivo je da je Pavelić smrtnu kaznu Galiću pretvorio u "5 godina teške tamnice", 21. veljače $1944 .{ }^{55}$

Stepinčevo 17. PISMo Paveliću, 8. kolovoza 1944. - Nadbiskup se zauzima kod Poglavnika da se udijeli pomilovanje za 54 hrvatska časnika, dočasnika i vojnika. Iz opširna pisma izdvajamo rečenicu da promjena "kazne smrti u drugu koju kaznu utjecat će bez sumnje kako na optužene tako i na njihove obitelji, koje bi njihovom smrću ostale bez hranitelja, da svoje živote stave u pravu službu naroda i države". ${ }^{56}$

Stepinčev osmi susRet s Pavelićem, 14. kolovoza 1944. Nadbiskupov tajnik vlč. Stjepan Lacković bilježi: "Dne 14. VIII. 1944. u 12,30 sati nadbiskup zagrebački i papinski delegat posjetili Poglavnika, predali pojedinačne molbe [pedeset i četvorice] i zamolili pomilovanje za sve osuđenike. ${ }^{157} \mathrm{Iz}$ te skupine 11 ih je osuđeno na smrt.

- I nadbiskup Stepinac i apostolski izaslanik Ramiro Marcone interveniraju kod Poglavnika. Međutim, izgledi su maleni.

Stepinčev deveti susRet s Pavelićem, 16. kolovoza 1944. Isti tajnik Lacković zabilježio je: "Dne 16. VIII. 1944. u 12 sati i 45 minuta nadbiskup zagrebački i papinski delegat posjetili Poglavnika, te su ponovno molili za pomilovanje čitave skupine." ${ }^{58}$

54 J. Batelja, BAS, III., str. 17-18; Stepinčev Dnevnik (neobjavljeno), 5. svezak (1942.-1944.), str. 167.

55 http://www.vojska.net/hrv/zivotopis/g/galic/vladimir/ (9. 11. 2016.); Jozo Tomasevich, Rat i revolucija u Jugoslaviji 1941-1945. Okupacija i kolaboracija, Europapress holding - Novi Liber, Zagreb, 2010., str. 485, navodeći I.S. Krajačića, piše: "Četvoricu, uključujući i Vladimira Galića, zapovjednika brigade Poglavnikova tjelesnog sdruga, ustaše su uhvatili i strijeljali..."

56 M. ŠKalić-ŠTAmbuk, nav. dj., str. 143.

57 M. ŠKalić-ŠTAMBUK, nav. dj., str. 144.

58 M. ŠKalić-ŠTambuk, nav. dj., str. 144. 
- Dvanaest godina poslije, u zatočeništvu, kard. Stepinac komentira svoje pohode Paveliću: "Teško je bilo meni ići često k Paveliću. No, kad je bila veća stvar po srijedi, morao sam ići. Zanimljivo je, da Pavelić nikada nije bio u [nadbiskupskom] Dvoru. Da je barem jedanput došao, alaj bi komunisti uživali! Koliko bi to bio argumenat za njihove laži!"59

- Ne samo da neustrašivi Nadbiskup nije "uglavnom ćutao", nego je "često" išao k Paveliću da intervenira u većim stvarima kao što smo i vidjeli.

Stepinčevo 18. PISMo Paveliću, 21. kolovoza 1944. - Nadbiskup moli Poglavnika "posljednji put" za pomilovanje jedanaestorice osuđenika na smrt zbog navodne suradnje s komunistima, uvjeravajući ga da će njegov "čin pomilovanja više koristiti Hrvatskoj nego li strijeljanja ovih nesretnika". ${ }^{60}$

- Nadbiskupov tajnik S. Lacković bilježi: "Ujutro dne 22. VIII. 1944. 10 optuženih i osuđenih odvedeno u Maksimir i strijeljano."61

Stepinčevo 19. PISmo Paveliću, 28. prosinca 1944. - Nadbiskup intervenira za oslobođenje Vladimira Ubla, pričuvnoga zastavnika.

- Negativan odgovor iz Poglavnikova vojnog ureda od 1. veljače 1945. Nadbiskupu je stigao 6. veljače, kako je to pribilježio tajnik Lacković. ${ }^{62}$

Stepinčevo 20. PISMo Paveliću, 20. ožujka 1945. - Stepinac se zauzima za ublaženje stanja u lepoglavskom zatvoru, u kojem su se već mjesecima nalazili neki sudionici "urote" poznate pod imenom Mladena Lorkovića, ministra vanjskih poslova, i Ante Vokića, ministra oružanih snaga, koji su potkraj kolovoza 1944. pali u Poglavnikovu nemilost te od 6. rujna i u zatvor. U Nadbiskupovu dnevniku stoji zapisano: "Rodbina ministra Dr. Lorkovića zamolila je Preuzvišenoga

59 J. Vraneković, Dnevnik, pod nadnevkom 19. veljače 1956., str. 463.

60 J. BATELJA, BAS, III., str. 63-64.

61 M. ŠKalić-Štambuk, nav. dj., str. 144; J. BAtelJa, BAS, III., str. 61.

62 J. BATELJA, BAS, III., str. 94; M. ŠKAlić-ŠTAMBUK, nav. dj., str. 156 donosi da je odgovor pisan 7. veljače. Možda je zabuna u čitanju brojeva 1 i 7 . 
Nadbiskupa, da bi se zauzeo za njegovo puštanje na slobodu. Tu se međutim ne može ništa učiniti! Interesantno je, da je isti g. Dr. Lorković prije nekog vremena predlagao na sjednici Hrv. drž. vlade, da se Preuzv. Nadbiskupa internira, jer je politički nepoćudan."63

Ovo je pismo objavljeno samo u talijanskom prijevodu. Budući da mu ne nalazimo izvornika, prevodimo ga na hrvatski. "Poglavniče, osjećam dužnost obratiti Vam se još jednom kao glavaru države u pitanju zatočenih političara koji se nalaze u Lepoglavi i u drugim koncentracijskim logorima. [...]

Doživljavam veliku nepriliku da opet interveniram u ovoj stvari nakon što sam toliko puta razgovarao s predstavnicima državnih vlasti. Dopustite mi ipak da predložim rješenje ovoga problema. Neko Povjerenstvo sastavljeno od članova Hrvatskoga sabora neka se pošalje na lice mjesta, da istraži stanje zatočenih, koji mu mogu slobodno izraziti svoje želje i svoja žaljenja, kakva god bila njihova religija. Mislim da će se na taj način u većem dijelu ušutjeti neugodni glasovi javnosti, dok bi jedna takva gesta mnogo koristila našemu međunarodnom ugledu i položaju.

Svraćajući Vašu pozornost na taj prijedlog, slobodan sam zamoliti Vas da mi dadnete na znanje ima li rodbina zatočenika manje razloga biti u strahu s obzirom na njihove mile."64

- Umjesto odgovora, pred pad NDH glavni su zavjerenici likvidirani "pod nerazjašnjenim okolnostima", kako se to obično kaže.

Stepinčevo 21. PISMo Paveliću, 2. travnja 1945. - Stepinac uoči obljetnice NDH, a samo mjesec dana prije svršetka rata i propasti NDH po dvadeset i prvi put šalje osobno pismo Paveliću moleći ga da se posluži svojim vrhovnim ovlastima i poštedi petoricu Srba koji su osuđeni na smrt. Uvjerava Pavelića da će njegov "čin pomilovanja baš prigodom predstojeće godišnjice osnutka naše Države najbolje djelovati". ${ }^{65}$

63 A. Stepinac, Dnevnik, sv. V., str. 281. Objavljeno u članku J. Batelja, "Temeljito i objektivno", u: Marulić, Zagreb, 5/2010., str. 1001-1013, citat: str. 1003.

64 F. Cavalli, nav. dj., str. 273-274.

65 J. BATElJA, BAS, III., str. 114-115; talijanski: F. CAVAlli, nav. dj., str. 272-273. 
- Odgovor je stigao 14. travnja "da je Poglavnik svojom milošću sve navedene pomilovao, zamienivši im smrtne kazne doživotnom težkom tamnicom". 66

\section{Neutvrdena datuma}

Pavelić poziva biskupe da brane državu. Stepinac u razgovoru $\mathrm{s}$ krašićkim župnikom 1956. kaže: "Kad je sve išlo svršetku, pozvao je Pavelić biskupe, da i oni kažu svoju riječ. Sastao se uži odbor Biskupskih konferencija. Izdali smo deklaraciju, što je bilo sasvim na mjestu, da i mi izrazimo volju i pravo hrvatskog naroda. Potpisnici svi izmakli, a ostao sam sâm, da i za to odgovaram. [Ivan] Šarić je pošao vani. [Jozo] Garić isto tako - i brzo umro. [Antun] Akšamović je zauzeo svoj stav. [Janka] Šimraka zatvorili i slomili, a ti nadbiskupe plati za sve! Hvala Bogu! Ali mi ne znamo za mržnju i zato opraštamo rado svima: Nijemcima, Talijanima, ustašama, partizanima, a i nekima iz naših redova. [...] Ali danas, nakon $11 \mathrm{~g}$. kad sve to gledam, uvjerenja sam, sudeći po Fatimskoj poruci i prilikama, da će se 1960. g. sve smiriti u svijetu. [...] Ali jedno trajno stoji: Gospodin Bog nikada ne gubi bitku!"67

- Godine 1960. nije se sve smirilo u svijetu. Preminuo je i smirio se u Gospodinu hrabri nadbiskup i kardinal Alojzije Stepinac. Gospodin Bog izvojštio je još jednu bitku! Možda je ovaj odlomak jedan od najsvjetlijih u Stepinčevu životu, izgovoren prije 60 godina: Poslovodni odbor petorice članova HBK sastaju se i sastavljaju famoznu deklaraciju kojom su osudili komunistička nasilja. I svi potpisali. Nakon potpisa: dvojica pobjegla, jednoga zatvorili i slomili, a drugoga slomili a da ga nisu ni zatvorili. Stepinac na bojišnici ostao sam kao Krist pred Poncijem Pilatom. On ne bježi, on se ne lomi, njega se zatvara i osuđuje i u zatočeništvu umire kao hrvatski heroj i kao katolički mučenik. Ali ni sve ovo ne bi bilo dostatno za proglašenje blaženim i svetim da nije izgovorio najkršćanskije riječi: "Ali mi ne znamo za mržnju i zato opraštamo rado svima: Nijemcima, Talijanima, ustašama, partizanima, a i nekima iz naših redova." Eto tako!

66 M. ŠKalić-ŠTAmbuk, nav. dj., str. 151; J. BATELJA, BAS, III., str. 122.

67 J. VRaneković, Dnevnik, pod nadnevkom 19. veljače 1956., str. 464. Riječ je o Izjavi, od 24. ožujka 1945. J. BATELJA, BAS, III., str. 109-113. 
Stepinčev deseti susRet s Pavelićem, prije sloma NDH. Pavelić je napustio Zagreb 6. svibnja $1945 .^{68}$ Stepinac se sjeća 1956. godine: "Ali kad je sve išlo kraju 1945. g., pozove me Pavelić. Vidio sam na njemu zabrinutost i on će in medias res: 'Znadete, da je tradicija, da su zagrebački biskupi vršili bansku čast u časovima, kad je izbila kakva neprilika. [...] I sada mi se kanimo na vrijeme povući, pa smatram, da biste Vi preuzeli i civilnu vlast u Hrvatskoj u svoje ruke...' - 'Poglavniče - velim mu - to je velika stvar i ja moram o tome dobro promisliti.' No, u duši imao sam gotov odgovor: Ne! Pristati na to značilo bi za nekoliko dana izgubiti život. I to bi bilo razumljivo. Naslijedio si $\mathrm{Pa}-$ velića, znači: i prije si bio s njim - odgovoran si za sve... i vješala! Nije moj odgovor 'ne' bio zato, da bih se bojao smrti. Daleko od toga. Ali radi ovakve stvari - kada je već sve jasno bezizgledno, ići u smrt, a ostaviti dijecezu, kler, narod - činilo mi se nerazborito. I onda komu će predati vlast?"69

- Time je Nadbiskup sve protumačio, a Pavelić pokazao kako mu je vlastita oholost, koju je najviše cijenio, bila prava životna neprijateljica.

Stepinac jedanaesti put intervenira, ali uzalud. Kao zatočenik u Krašiću 1953. Stepinac se prisjeća ne naznačujući nadnevak ratnoga vremena: "Veliki župan [Stjepan] Uroić molio me je da velim Paveliću, da raspusti vojnicu, jer čemu dvije vojske? Učinio sam po želji tog župana, ali Pavelić će kratko: 'Bez ustaške vojnice nema hrvatske države.' - Pa što sam onda mogao?"70

- Godine 1945. nastradale su obje: i domobranska vojska i ustaška vojnica! I hrvatska država!

Stepinčeva reakcija na atentat na Pavelića, 1957. Kada je preko radija čuo da je na Pavelića u Argentini izvršen atentat, Nadbiskup je rekao: "Žao bi mi bilo, da mu se zlo dogodi, makar se nismo u mnogom slagali i ljutih mi je jada zadao. Bog sâm može prosuditi. Ja ga

68 "Pavelić, Ante", u: Hrvatska enciklopedija, 8, Zagreb, 2006., str. 334.

69 J. VRaneković, Dnevnik, pod nadnevkom 19. veljače 1956., str. 463. Vidi također str. 297.

70 J. VRaneković, Dnevnik, pod nadnevkom 12. prosinca 1953., str. 236-237. 
više puta nisam mogao razumjeti. Kad sam mu i prigovorio, znao je reći: 'Moja je savjest pred historijom mirna'."71

- Kako može biti mirna takva savjest koja je zadala toliko "ljutih jada" Nadbiskupu, što Bog zna i povijest bilježi, i toliko ljutih jada cijelomu hrvatskom narodu!

Zaključak. Ne znam je li bilo koje molbe, žalbe ili tužbe hrvatske, židovske, srpske ili bilo koje druge na Stepinčevu stolu a da on nije intervenirao kod državnih vlasti. U 48 mjeseci trajanja NDH Stepinac je kod Pavelića izričito i izravno intervenirao 32 puta: osobno 11 i napismeno 21 put. Pavelić mu nije izravno odgovorio ni na jedan dopis, a kamoli da bi ikada uzvratio posjet. Stepinac je dostojanstveno očuvao sve ljudske norme, forme i manire a pogotovo kršćanske vrline u ophođenju s Poglavnikom pokazujući mu kako bi i on trebao biti kulturan prema drugima. Stepinac je pokazao kako je velikodušan prema potrebnima, koji su se njemu obraćali za pomoć, a dostojanstven prema silnicima ovoga svijeta. Pavelić, međutim, kao da iz četverogodišnjega komuniciranja $s$ Nadbiskupom nije ništa naučio, pogotovo nije ništa držao do ustaljena crkvenog stila i postupka. Nije se ni potrudio iz stadija neukroćene osvete prijeći u pošteno čovjekoljublje niti se odrekao mržnje kao najrazornije ljudske strasti. Kako se osvetom i mržnjom jednu državu može stvarati i njome ravnati? Mržnja je propast za svaku osobu i za svako ljudsko društvo bez obzira na oblik, opseg i razinu.

Već 6. travnja 1941. skopski biskup Smiljan "Čekada bî teže ranjen, odmah pođe u svoj rodni kraj [Donji Vakuf] liječiti rane, a dođe u dodir i s nekim vrhovima NDH i otvoreno naglasi moralna načela, koja moraju voditi hrvatsku vladu i državu, ako misle opstojati pod nebom", ${ }^{72}$ zapisao je don Ivan Tomas, njegov tajnik (od studenoga 1940. do siječnja 1941.). Koliko se sjećam iz razgovora s don Ivanom u Rimu, možda je upravo tom zgodom biskup Čekada posjetio i podsjetio Pavelića i druge "vrhove NDH" na spomenuta "moralna načela". A on mu je s visoka htio zatvoriti usta: "Gospodine biskupe, Vi ne znate kako se država stvara." $\mathrm{Na}$ to mu je Čekada biskupski smjelo

71 J. VRaneković, Dnevnik, pod nadnevkom 11. travnja 1957., str. 535; vidi također str. 236.

72 I. Tomas, "Nadbiskup dr. Smiljan Franjo Čekada /1902.-1976./", u: Hrvatska revija, Barcelona, 1/1977., str. 133. 
uzvratio: "Gospodine poglavniče, ja ne znam kako se država stvara, samo znam da se tako ne stvara!" Da je uistinu znao kako se država izgrađuje, ne bi onako postupio ni s hrvatskim narodom ni s hrvatskom državom. I povijest bi nam od 40 -ih godina prošloga stoljeća do danas bila sigurno mirnija. Ne bi ni onoliko patnje bilo podneseno, ni onoliko krvi proliveno, ni onoliko suza istočeno. I nedavnoga Domovinskog rata možda ne bi bilo.

Kao što je Pavelić po mraku ušao u Hrvatsku 1941., tako je po mraku iz nje i pobjegao 1945. Kod Maribora dao je izjavu "neka se svaki spašava kako znade", ${ }^{73}$ prepustivši narod u Hrvatskoj jugokomunističkoj nasilničkoj, osvetničkoj i mrziteljskoj kami i jami, i ostavivši za sobom Strahotu pustoši!

A nadbiskup Stepinac zbog svojih kardinalnih krjeposti razboritosti, pravednosti, jakosti i umjerenosti imenovan je kardinalom 1953., te zbog svoga evanđeoskog svjedočenja pod sva tri protuljudska totalitarizma - fašizmom, nacizmom i komunizmom - i zbog svoga herojskoga mučeništva bî ubrojen u antologiju katoličkih mučenika i blaženika 1998. Nije dakle "uglavnom ćutao", nego je uglavnom govorio i to glasom Evanđelja, katoličkoga morala i ljudskih prava!

Blaženi Alojzije, mučeniče, blaženuj i vjekuj u Bogu i moli za nas na zemlji!

73 V. Cecelja, nav. čl., str. 733. 


\section{Stepinac's Interventions with Pavelic}

\section{Summary}

Serbian Patriarch Irinej Gavrilovic addressed Pope Francis on April 30, 2014, asking him to reject the canonization of the martyr Blessed Aloysius Stepinac, the Archbishop of Zagreb (a coadjutor from 1934, an ordinary from 1937 to 1960, sede impedita from 1946 - in jail until 1952 and in detention until his death). The Patriarch's cause against canonization: Archbishop Stepinac was "mostly silent" about everything that was happening in the Independent State of Croatia (NDH). And, silence is consent. Such a church representative cannot be a Christian model. The author of this paper, based on the evidence published before the $\mathrm{Pa}$ triarch's letter, has shown that Archbishop Stepinac, during the period of four years of NDH from April 10, 1941 to May 8, 1945, i.e. for 48 months, intervened more than 360 times in personal meetings with Croatian authorities in Zagreb either by mail to some Croatian ministers, or through public sermons, persuasions and lectures. In particular, the author has focused on the contacts between archbishop Stepinac and Ante Pavelic, the head of NDH. He summarized and chronologically presented 21 letters of Stepinac to Pavelic and 11 meetings of Stepinac with Pavelic, with brief comments attached. Pavelic neither returned a single visit nor personally responded to Stepinac's letters. Nevertheless, the Archbishop was persistent and resolute and intervened whenever he considered it necessary to do so, no matter how political authorities felt about his letters, inquiries and requests. Therefore, Archbishop Stepinac was not silent, he was speaking, writing, and mediating as much as he could, regardless of the results of his interventions. At least, it cannot be said that Archbishop Stepinac was "mostly silent" about all that was happening at the time of NDH. When Pavelic saw that everything went wrong and had to flee from Croatia, he invited Archbishop Stepinac and offered him to take control over Croatia. Stepinac rejected the offered political power remaining at his archbishop's position.

Keywords: Pope Francis; Patriarch Irinej; Blessed Aloysius Stepinac, Archbishop; poglavnik (leader) Ante Pavelic; Independent State of Croatia; Croatian Bishops' Conference. 